Kampus 4 Universitas Ahmad Dahlan Jl. Ringroad Selatan, Tamanan, Banguntapan, Bantul

Daerah Istimewa Yogyakarta 55191

Telp. : (0274) 563515 Fax. : (0274) 564604

e-mail : ihtifaz@uad.ac.id

Vol.1, No 1\&2, Juni-Desember 2018, pp. 1-20

ISSN p:2622-4755 e:2622-4798.

DOI: https://doi.org/10.12928/ijiefb.v1i1.284

\title{
In Search for Islamic Macroprudential Policy in Indonesia: The Case of Financing to Value (FTV) and Property Financing
}

\section{Abdul Qoyum ${ }^{1} *$, Neneng Ela Fauziyyah ${ }^{2}$}

${ }^{1}$ State Islamic University Sunan Kalijaga Yogyakarta, Jalan Laksda Adisucipto, Catur Tunggal, Depok, Sleman, Yogyakarta 55281

2International Islamic University Malaysia, P.O. Box 10, 50728 Kuala Lumpur, Malaysia

*e-mail: qoyum13@gmail.com 


\title{
In Search for Islamic Macroprudential Policy in Indonesia: The Case of Financing to Value (FTV) and Property Financing
}

\author{
Abdul Qoyum ${ }^{1} *$, Neneng Ela Fauziyyah ${ }^{2}$ \\ ${ }^{1}$ State Islamic University Sunan Kalijaga Yogyakarta, Jalan Laksda Adisucipto, \\ Catur Tunggal, Depok, Sleman, Yogyakarta 55281 \\ ${ }^{2}$ International Islamic University Malaysia, P.O. Box 10, 50728 Kuala Lumpur, \\ Malaysia \\ *e-mail: qoyum13@gmail.com
}

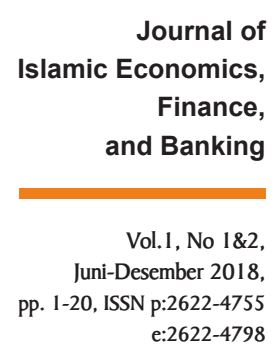

\begin{abstract}
This study aims to examine the impact of macroprudential policy particlarly the relaxing of Financing to Value (FTV) on property financing of Islamic bank in case of Indonesia. In addition, this paper also analyzes the impact of macroeconomic variables and specific factors on property financing in Islamic Bank. This paper collects data from the Bank Indonesia website, the Financial Services Authority (FSA) and the Central Statistics Agency (CSA) form January 2010 until April 2016. By employing Vector Error Correction Model (VECM), this study found that inflation and Industry Produce Index (IPI) have been positively influence on the property financing, while the BI rate and financing to deposit ratio (FDR) have been negatively influence on the property financing. While the relaxing of FTV policy also negatively influence on the property financing. Therefore, This study conludes that the policy have not effectived yet.
\end{abstract}

\section{Keywords:}

Macroprudential Policy, Financing to Value (FTV), Property Financing, Vector Error Correction Model (VECM)

\begin{abstract}
Abstrak
Penelitian ini bertujuan untuk menguji dampak dari kebijakan makroprudensial terutama relaksasi dari Pembiayaan terhadap Nilai (FTV) pada pembiayaan properti bank syariah dalam kasus Indonesia. Selain itu, makalah ini juga menganalisis dampak variabel makroekonomi dan faktor-faktor spesifik pada pembiayaan properti di Bank Islam. Makalah ini mengumpulkan data dari situs web Bank Indonesia, Otoritas Jasa Keuangan (OJK) dan Badan Pusat Statistik (CSA) formulir Januari 2010 hingga April 2016. Dengan menggunakan Vector Error Correction Model (VECM), studi ini menemukan bahwa inflasi
\end{abstract}

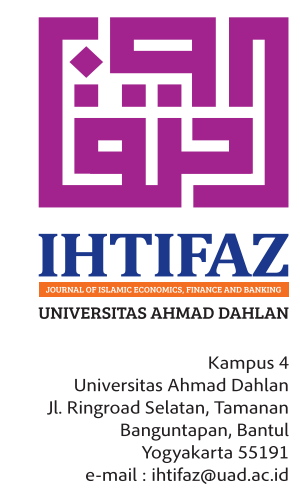

Ihtifaz: Journal of Islamic Economics, Finance, and Banking 
dan Produksi Industri Indeks (IPI) telah memberikan pengaruh positif pada pembiayaan properti, sementara BI rate dan financing to deposit ratio (FDR) kebijakan FTV juga berpengaruh negatif terhadap pembiayaan properti. Oleh karena itu, penelitian ini menyisihkan bahwa kebijakan belum efektif.

\section{Kata Kunci:}

Kebijakan Makroprudensial, Pembiayaan Terhadap Nilai (FTV), Pembiayaan Properti, Model Koreksi Kesalahan Vektor (VECM)

\section{INTRODUCTION}

Global financial crisis which happened in 2007-2008 has caused the failed of many financial institutions in the world, including in Indonesia. This crisis has been bringing on the detoriate of financial and payment system (Herarti, 2015). Therefore, Bank of Indonesia as policymakers has revised their policies related to the financial stability including macroprudential policy.

On of the most crucial policy in which has been taken by Bank of Indonesia in facing these crisis is by controlling credit for property sector. This policy is called Loan to Value (LTV) for conventional banking and Financing to Value (FTV) for Islamic banking. LTV/FTV is the percentage of collateral or Down Payment that must be provided by debtor compared to the total of loan. Therefore, when the growth of property is high and tend to the economic bubble, LTV/FTV is very useful to reduce this growth.

Policy for tightening of LTV/FTV in 2013 has been caused the increased the growth of cerdit for property. It can be seen from the figure 1 , whereby the property credit growth in 2013 decreased significantly at $15.66 \%$ from $26.56 \%$ in 2012 . Nevertheless, that policy has big impacts on property credit until 2015. As result, Bank Indonesia releases the relaxing of LTV/FTV property policy to boost the credit growth.

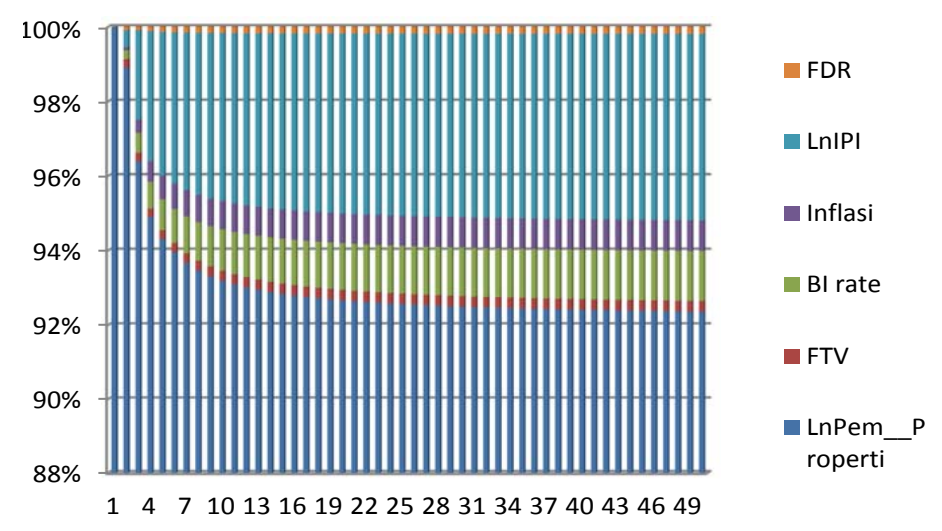

Figure 1. Growth of Property Credit in 2012-2015 
Credit for roperty is also influenced by other factors beside LTV/ FTV, namely both the internal factor (banking) and macroeconomic factors. According to Aviliani (2015: 380), financial instability could affect the banks' performance, especially in the property credit. There are some studies related to macroprudential policy and property financing. Pradana and Sampurno (2013) shows that BI rate is the most important variable that has impact on the volume of credit for property. The other variables that have significant impact on Credit for Property are Loan to Deposit Ratio (LDR), Capital Adequacy Ratio (CAR), Return on Asset (ROA) and inflation. In addition, Marisza (2015) also shows that inflation and interest rate has negative on credit volume, but for LDR has positive impact.

Although in the conventional literature, there are some studies on the issue of macroprudential policy related to the credit for property, but the research on Islamic Macroprudential is still limited. Therefore, the objective of this study is aimed to examine the impact of macroprudential policy in particular about the relaxing of Financing to Value (FTV) on the property financing in Islamic bank in Indonesia. Moreover, this research also will analyze the impact of macroeconomic variables and internal factor on the credit for property.

The organization of the paper is as follows; section II Provided literature review. Section III outlines the data and the methodology. Section IV of the result and discussions and in the section $V$ shows the conclution of main finding and Policy Recommendations.

\section{LITERATURE REVIEW}

\section{General Concept of Macroprudential Policy}

The Issue of macroprudential policy has been more popular in Indonesia after the global financial crisis in 2008. Bank of Indonesia as a regulator, setting it and released the legal foundation, namely Bank Indonesia act. No.16/11/PBI/2014 regarding to macroprudential regulation and supervision at July, 01, 2014. As Mentioned by Bank Indonesia (2015), generaly, macroprudential policy leads to more overall analysis on the financial system rather than individual financial institution. Utari and Arimurti (2012) describes that a fundamental concern of macroprudential policy is a prudential regulatory instrument which is used to achieve stability in the whole financial system and not just the individual health of the financial institution. Macroprudential policy is needed to anticipate and mitigate financial risk.

The implementation of macroprudential policy is not only can eliminate the vurnerability of the financial system to the financial shock but also can support the stability of the financial system, enhance market resilience and reserve as an early warning system to anticipate potential crisis in the future. Hence, there are three important goals in the implementation of macroprudential policy such as: 
1. Preventing financial imbalances

2. Reducing systemic risk that arises from inter-linkages, common exposures and procyclicality of the financial system, and

3. Discouraging risk taking of financial institutions that may have systemic implication.

According to Delgado and Mynor (2011) in Purnawan and Nasir (2015), the use of macroprudential instruments is not a new thing, however more macroprudential instrument are needed after the global financial crisis in 2008. Off courses, it is depend on the level of economic growth, exchange rate, and durability toward a financial shock. That instruments are used often as a complementary for monetary policy and fiscal policy. Some Macroprudential policy that used in Indonesia is as described in table 1. Each of instrument is used for mitigating the risks such as credit risk, liquidity risk, governance risk and capital risk.

Table 1. The Instrument of Macroprudential Policy

\begin{tabular}{lll}
\hline Risk & \multicolumn{1}{c}{ Instruments } \\
\hline Credit & 1. & Loan to Value (LTV) ratio \\
& 2. & Financing to Value (FTV) ratio \\
& 3. & Statutory Minimum Loan to Deposit Ratio (LDR \\
& Reserve) \\
Liquidity & 4. & Lending Rate (prime lending rate) \\
& 5. & Statutory Minimum Loan to Deposit Ratio (LDR \\
& & Reserve) \\
Governance & 6. & Net Open Position (NOP) \\
Capital & 7. & Lending Rate (prime lending rate) \\
& 8. & Counter-Cyclical Capital Buffer(CCB) \\
& 9. & Capital Surcharge \\
\hline
\end{tabular}

Source: Bank Indonesia (2015)

\section{Financing to Value (FTY)}

FTV is the ratio between the value of financing that can be provided by Islamic banks against the collateral value of the property at the time of the provision of financing by the price of the last assessment (Bank Indonesia Regulation No. 17/10/PBI/2015, 2015). This policy set the magnitude of the amount of credit that can be disbursed by banks to customers with a decrease or increase in payment (down payment) (Budiyanti, 2015).

As for FTV, the calculation of the financing is set according to the type of contract used are:

1. Murabahah or contract Istishna '. Funding is determined based on the cost of financing given to customers in accordance with the initial contract. 
2. Akad Musharaka Mutanawisah (MMQ). Set based on the inclusion of banks for ownership of the property as stated in the financing agreement.

3. Ijarah muntahiya Bittamlik. Funding is determined based on the result of reduction in property prices with a deposit as detailed in the financing agreement.

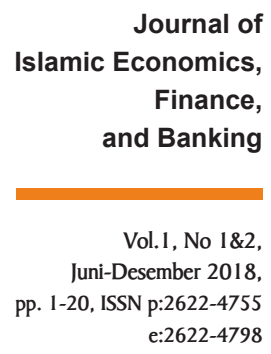

\section{Macroeconomic Theory and Internal Factor of Islamic Banking BI Rate}

The monetary target of Bank of Indonesia is controlling the value of the rupiah through inflation with BI rate policy. In monetary theory, this policy is called the discount rate (discount rate). If the discount rate was increased, the ability of banking for lending the money will decreased. Therefore, the amount of money in circulation was reduced and inflation can be prevented (Nopirin, 2014). In general, the central bank will raise the BI rate when inflation rises higher than a specified target and vice versa. When the BI rate is increased it will affect the rising interest rates on deposits which further affect the higher lending rates.

\section{Inflation}

Boediono (2005) states that inflation is the rising prices in general and continuously. Some of the causes of inflation are rising private consumption, excessive liquidity in the market that triggered consumption and speculation, including their disfluencies in the distribution of goods both iu due to natural disasters or due to human moral hazard. Firdaus and Ariyanti (2004) in Setifandy (2015) stated that in lending, although credit goes smoothly where the debt principal and interest are met, but over time, the value of money will stay down because of inflation and the purchasing power of money will be lower compared to when the credit is given.

\section{Industrial Production Index (IPI)}

Industrial Production Index is an economic indicator that name in it calculated the real production output of the manufacturing industry, mining and other manufacturers such as gas and electricity (Forex Indonesia: 2016). IPI is typically developed to measure increases and decreases in production output both on large and medium industries. IPI also a proxy of economic growth. Industrial Production Index can be used as a leading indicator of economic condition of a country. The level of production in a manufacturing company has a correlation with the level of employment and labor income and can also be used as a barometer of the dynamics that operate in the business cycle (Forex4you: 2016). 


\section{FDR}

FDR is a ratio that compares the financing to the third-party IHTIFAZ - JIEFB funds. This ratio indicates how much money is able channeled to financing obtained from third party funds (Adzimatinur et.al., 2016). The higher the ratio of FDR, the ability of Islamic banking in the finance portfolio also getting bigger. FDR also be used to measure the liquidity of Islamic banking. Many studies have been done related to on how the influence of internal factors and macroeconomic factors on the banking loan portfolio, namely property financing as well as how the effectiveness of FTV policy in regulating excessive lending. Titia Dwianingrum (2015) examines the Distribution Rate Determination mortgage (Period After Policy Loan to Value) at 5 Commercial Banks in Indonesia. This study uses a quantitative method with regression analysis of panel data which result in that amount of lending mortgage bank BTN, BNI, BCA, Mandiri and CIMB Niaga better take into account the changes in the variable DPK, LDR while the NPL, CAR, ROA, ROA and BI Rate not too taken into account in determining the amount of the mortgage loan portfolio.

Another study conducted by Ida Ayu Putri Saraswati (2014) with the title of Bank Indonesia Policy Analysis of the Loan to Value at PT. State Savings Bank (Persero).Tbk Branch Singaraja. This study used qualitative descriptive analysis that produces that Bank BTN branches of Singaraja LTV implementing provisions issued by Bank Indonesia in 2013, the impact faced by the bank in the form of a decrease in mortgage loans and there is competition between banks in extending credit. BTN Bank branch Singaraja mitigate the impact by conducting joint cooperation in the provision of mortgage developer.

Additionally, Marisza (2015) with the title Analysis of Effect of Policy Loan to Value (LTV), Inflation, Interest Rate and Loan to Deposit Ratio (LDR) to the Home Loan Disbursement Period Lampung 2010: 01-2014: 09 examines the influence LTV pengetatatan policy against property loans in the banking area of Lampung. The results of this study explains that inflation and interest rates negatively affect the amount of the mortgage portfolio, and LDR have a significant effect. While the period before and after the policy is a significant difference, LTV policy fails to suppress the amount of the mortgage portfolio in Lampung Province.

Based on previous studies, no studies have focused on the influence of macroprudential policy instruments especially LTV/FTV against property financing in Islamic banking Indonesia so that the research is quite different from the objects, variables, and tool of analysis.

\section{DATA AND METHODOLOGY}

\section{Data}

This study uses data in the form of monthly time series for the period from January 2010 to April 2016. Data were obtained from the publication of Bank Indonesia, the Financial Services Authority, as well 
as the Central Bureau of Statistics of Indonesia. The variables used are the property financing variables, FTV, BI rate, Inflation, Industrial Production Index (IPI), and FDR. In detail, the data can be seen in the following table 2 .

Table 2. Variable and Sources of Data

\begin{tabular}{lcc}
\hline Variable & Definition & Source \\
\hline $\begin{array}{l}\text { Property } \\
\text { Financing }\end{array}$ & $\begin{array}{c}\text { Total property finance in Islamic } \\
\text { banking from home footprint, flats } \\
\text { and houses shops } \\
\text { Macroprudential instruments }\end{array}$ & $\begin{array}{c}\text { Financial Fervices } \\
\text { Authority }\end{array}$ \\
FTV & $\begin{array}{c}\text { Moverning credit risk, especially in the } \\
\text { property and motor vehicles }\end{array}$ & Bank Indonesia \\
BI rate & $\begin{array}{c}\text { Indonesia Bank Interest Rate } \\
\text { Inflation }\end{array}$ & $\begin{array}{c}\text { Bank Indonesia } \\
\text { IPI }\end{array}$ \\
FDR & Industrial Production Index & $\begin{array}{c}\text { Bank Indonesia } \\
\text { Central Bureau of }\end{array}$ \\
& Financing to Deposit Ratio & Financial Fervices \\
& & Authority \\
\hline
\end{tabular}

\section{Methodology}

Vector error correction model is a VAR model is restricted to nonstationary variable data which are known to have co integration or possible long-term impact. In general, the steps in using the model VAR/VECM starting with stationary test the data, and then test the length of inaction (lag) is optimal, stability testing VAR/VECM, Granger causality test and cointegration test, estimation of the VAR model, Impulse Response Function (IRF) and Forecast Error Variance Decompotition (FEDV). these steps can be described in the following figure 2.

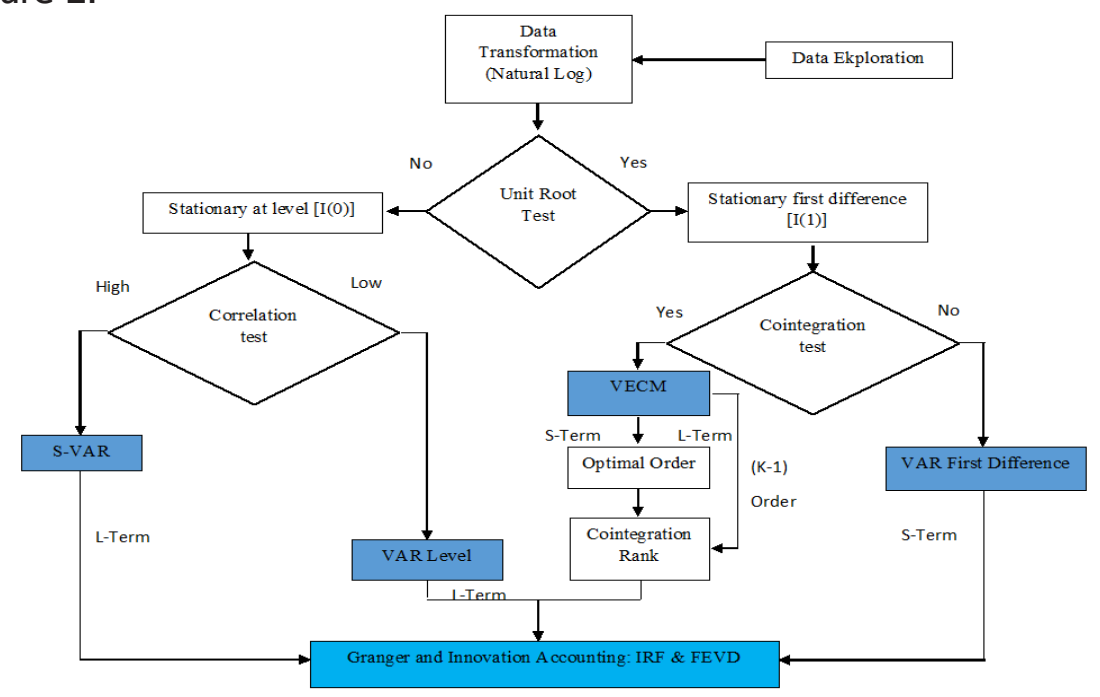

Figure 2. VAR Analysis Process 
In this study, we follow VAR models from Sahabat (2009) and Nasir (2008) with such modification as the different variables.

\section{IHTIFAZ - JIEFB}

LnPemb.Propertiy $_{t}=\mathrm{C}_{1}+\mathrm{a}_{1}$ LnPemb.Propertiy $_{t-1}+\Sigma \mathrm{a}_{1} \mathrm{FTV}_{t}+$ $\Sigma a_{1}$ BI rate $t_{t-1}+\Sigma a_{1}$ Inflation $_{t-1}+\Sigma a_{1}$ LnIPI $_{t-1}+\Sigma a_{1}$ FDR $_{t-1}+\varepsilon_{i}$

Where:

$\begin{array}{ll}\text { LnPemb.Properti } & =\text { Total Property Financing } \\ \text { FTV } & =\text { Financing to Value } \\ \text { BI rate } & =\text { Interest Rate } \\ \text { Inflation } & =\text { A general Increase in prices } \\ \text { LnIPI } & =\text { Industrial Production Index } \\ \text { FDR } & =\text { Financing to Deposit Ratio } \\ \varepsilon_{i} & =\text { Error Term }\end{array}$

\section{Finding and Discussions}

\section{Findings}

Model VAR/VECM has several steps to achieve the intended results of which are stasionaritas test data, the optimal lag test, Granger stability test, stability test VAR/VECM and other test like yan've seen from the picture above.

\section{Stasionaritas Test Data}

Stasionaritas test data in this study using formal testing by the unit root test (unit root test). The method used is the Augmented Dickey Fuller (ADF) and test the Philips Peron (PP). Here are the results of testing the method ADF and PP at current level:

Table 3. Method Test Results Stationarity ADF and PP Level Level

\begin{tabular}{lrrrr}
\hline \multicolumn{1}{c}{ Variable } & \multicolumn{2}{c}{ ADF } & \multicolumn{3}{c}{ Philips-Perron } \\
& T-Stats & Prob. & T-Stats & Prob. \\
\hline Pemb. property & 1.694603 & 0.7441 & -1.914109 & 0.6373 \\
FTV & -1.106084 & 0.9208 & -1.106084 & 0.9208 \\
BI rate & 1.806894 & 0.6915 & -1.567003 & 0.7967 \\
Inflation & -2.621723 & 0.2722 & -2.104965 & 0.5345 \\
IPI & $-6.886215 *$ & 0.0000 & $-6.897410 *$ & 0.0000 \\
FDR & -1.514768 & 0.8159 & -1.671223 & 0.7543 \\
\multicolumn{5}{c}{-4.085092} \\
1\% Level & Test Critical values (MacKinon) & -4.085092 \\
5\% Level & \multicolumn{5}{c}{-3.470851} \\
10\% Level & Note: * indicates a data stationary at current level & -3.470851 \\
\multicolumn{1}{c}{ ** Indicates data at the level of the first difference stsioner }
\end{tabular}


Table 3 explains that the current level by using ADF and PP, simply IPI variables are stationary with the value of T-Stats $6.886215>$ value MacKinon critical value that is less than $1 \%$ of $4.085092,3.470851$ amounted to $5 \%$ and $10 \%$ by 3.162458 . Meanwhile, other variables such as property finance, BI rate, inflation, FTV and FDR is not stationary at the current level because it has the T-statistics are less than the critical value MacKinon.

The test results above suggest that the data are not stationary at level, so that the required testing at the next level is the first difference. Below are the results of testing in the first difference:

Table 4. Method Test Results Stationarity ADF and PP Different First Level

\begin{tabular}{lcccc}
\hline \multirow{2}{*}{ Variable } & \multicolumn{2}{c}{ ADF } & \multicolumn{2}{c}{ Philips-Perron } \\
& T-Stats & Prob. & T-Stats & Prob. \\
\hline Pemb. Property & $-7.832424 * *$ & 0.0000 & $-7.835955 * *$ & 0.0000 \\
FTV & $-8.795663 * *$ & 0.0000 & $-8.795663 * *$ & 0.0000 \\
BI rate & $-4.731276 * *$ & 0.0014 & $-4.731276 * *$ & 0.0014 \\
Inflation & $-6.219345 * *$ & 0.0000 & $-5.927075 * *$ & 0.0000 \\
IPI & $-8.218785 * *$ & 0.0000 & $-8.218785 * *$ & 0.0000 \\
FDR & $-8.575537 * *$ & 0.0000 & $-8.575537 * *$ & 0.0000 \\
\multicolumn{5}{c}{-4.086877} \\
1\% Level & Test Critical values (MacKinon) & \\
5\% Level & \multicolumn{5}{c}{-3.471693} \\
10\% Level & Note: $*$ indicates a data stationary at Current level \\
\multicolumn{1}{c}{$* *$ Indicates data at the level of the first difference stationary }
\end{tabular}

Table 4 shows that the level of the first difference by using ADF and $\mathrm{PP}$, all variables have a value of $\mathrm{t}$-Stats $>$ value MacKinon critical value at $1 \%$ of $4.086877,3.471693$ amounted to $5 \%$ and $10 \%$ by 3.162948 .

\section{Optimal Lag Test}

This steps is taken to determine the most optimal lag is to see the value of AIC, SC and HQ lowest. In table 5 below are the results of testing optimal lag:

Table 5. Optimal Lag Test Results

\begin{tabular}{crrr}
\hline lag & \multicolumn{1}{l}{ AIC } & \multicolumn{1}{c}{ SC } & \multicolumn{1}{c}{ HQ } \\
\hline 0 & 9.961122 & 10.15385 & 10.03768 \\
1 & $-2.126564 *$ & $-0.777467^{*}$ & $-1.590686 *$ \\
2 & -1.850309 & 0.655157 & -0.855108 \\
3 & -1.493997 & 2.167838 & -0.039472
\end{tabular}




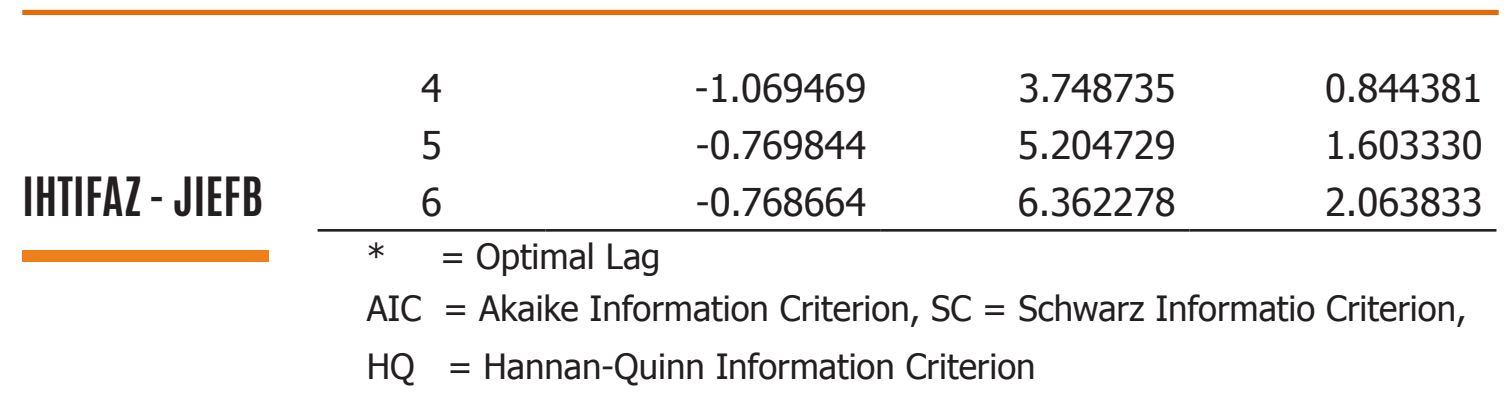

Table 5 illustrates the lowest value of the indicator AIC, SC and HQ is at lag 1 with a value of $-2.126564,-0.777467$ and -1.590686 . Thus, all the indicators recommended as the optimallag 1 so that it can be concluded that any shock that in one variable will be responded by other variables with a lag time of one period.

\section{Stability Test VAR / VECM}

The test results show that the system stability VAR VAR/VECM built stable. It is seen from the modulus of which is entirely under one as shown in table 6 below:

Table 6. Stability Test Results VAR / VECM

\begin{tabular}{lr}
\hline \multicolumn{1}{c}{ Root } & \multicolumn{1}{c}{ Modulus } \\
\hline 0.491764 & 0.491764 \\
0.326845 & 0.326845 \\
$-0.216893-0.023230 \mathrm{i}$ & 0.218133 \\
$-0.216893+0.023230 \mathrm{i}$ & 0.218133 \\
$0.008498-0.079895 \mathrm{i}$ & 0.080345 \\
$0.008498+0.079895 \mathrm{i}$ & 0.080345 \\
\hline
\end{tabular}

In addition to seeing the value of modulus, stability VAR/VECM can also be detected using AR Roots chart. The dots in the picture are in the loop, not out of the circle line. Thus, we can conclude that the model VAR/VECM built stable. Conclusions can be seen in the results chart AR Roots as follows in figure 3.

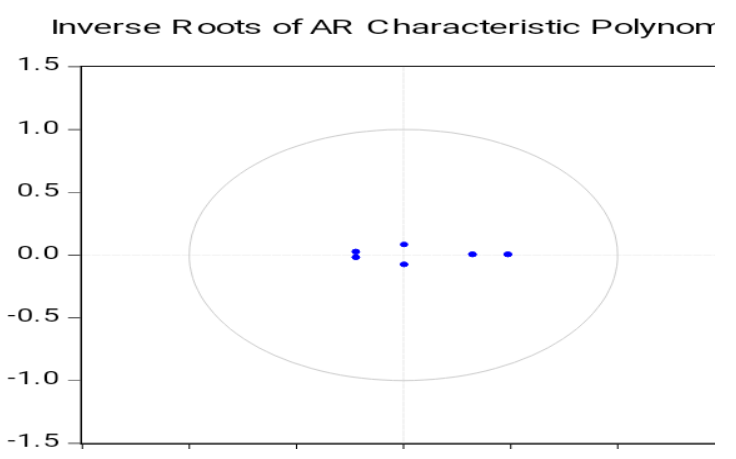

Figure 3. Graph Test Results AR Roots 


\section{Johansen Cointegration Test}

The test results were compared between Trace Statictic value and the value of Maximum Eigenvalue with critical value at $5 \%$ alpha as well as by looking at the probability value to indicate whether there is cointegration in the VAR system is outlined in the following table 7.

Table 7. Results of Johansen Cointegration Test

\begin{tabular}{|c|c|c|c|c|}
\hline \multicolumn{5}{|c|}{ Unrestricted Cointegration Rank Test (Trace) } \\
\hline $\begin{array}{l}\text { Hypothesized } \\
\text { No. of CE (s) }\end{array}$ & Eigenvalue & $\begin{array}{c}\text { Trace } \\
\text { Statistic }\end{array}$ & $\begin{array}{c}\text { 0:05 } \\
\text { Critical Value }\end{array}$ & . $* *$ \\
\hline none * & 0.489643 & 117.3072 & 95.75366 & 0.0008 \\
\hline \multicolumn{5}{|c|}{ Unrestricted Cointegration Rank Test (Maximum Eigenvalue) } \\
\hline $\begin{array}{l}\text { Hypothesized } \\
\text { No. of CE (s) }\end{array}$ & Eigenvalue & $\begin{array}{l}\text { Max-Eigen } \\
\text { Statistic }\end{array}$ & $\begin{array}{c}\text { 0:05 } \\
\text { Critical Value }\end{array}$ & Prob. ** \\
\hline none * & 0.489643 & 49.77574 & 40.07757 & 0.0030 \\
\hline At most $1 *$ & 0.369813 & 34.16872 & 33.87687 & 0.0462 \\
\hline
\end{tabular}

$*$ Denotes rejection of the hypothesis at the 0:05 level

** MacKinnon-Haug-Michelis (1999) p-values

Cointegration test results in table 7 shows the value of Trace Statistic of the Trace test of 117.3072 is greater than the critical value at $5 \%$ alpha is 95.75366 mean that there is one cointegration equation is built. Later in the Maximum Eigenvalue test, the value of maxeigen his statistic- of 49.77574 and 34.16872 sequentially greater than the critical value is 40.07757 and 33.87687 . It is clear that there are two equations that terkoitegrasi in the system. Thus, all variables tested cointegrated or have a long-term relationship.

\section{VECM Model Estimation}

Based on the analysis, inaction endogenous variables in the VAR system is statistically insignificant possibility. In addition, the interpretation of analytical results VECM too difficult, so commonly used in the analysis of the test VECM is Impulse Response Function (IRF) and the Forecast Error Variance Decomposition (FEDV) in interpreting the results.

\section{Impulse Respone Function (IRF)}

IRF test results to see the effectiveness of policy easing FTV, macroeconomic variables and internal factors of Islamic banks can be seen in the above chart in figure 4 . The second graph shows that the response to the shock of the property financing policy variables FTV is negative. At the beginning of the period until the 5th period fluctuations. But then stabilized until the end of the observation period with a standard deviation of -0.3586 .

Ihtifaz: Journal of Islamic Economics, Finance, and Banking
Journal of

Islamic Economics,

Finance,

and Banking

Vol.1, No 1\&2, Juni-Desember 2018, pp. 1-20, ISSN p:2622-4755 e:2622-4798 


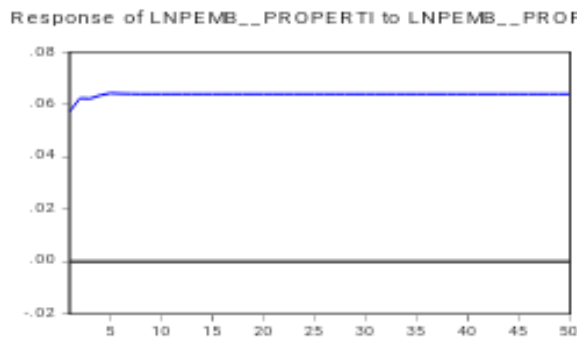

Response of LNPEMB__PROPERTI to BI_RATE

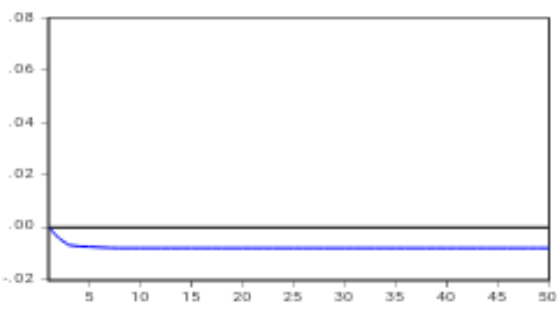

Response of LNPEMB PROPERTI to LNIPI

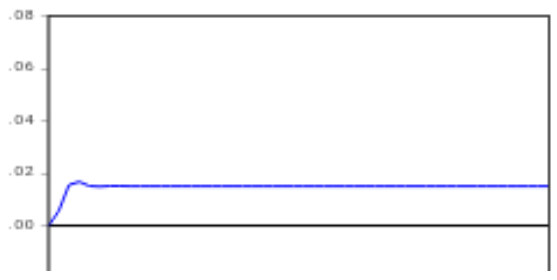

Response of LNPEMB_-_PROPERTI to FTV

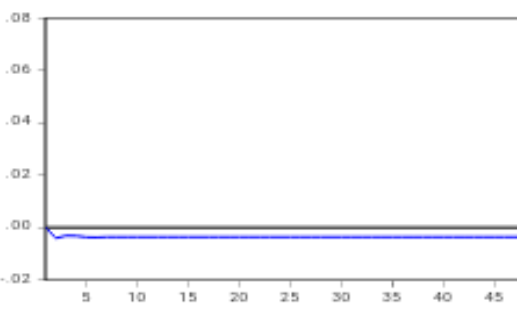

Response of LNPEMB__PROPERTI to INFLA:

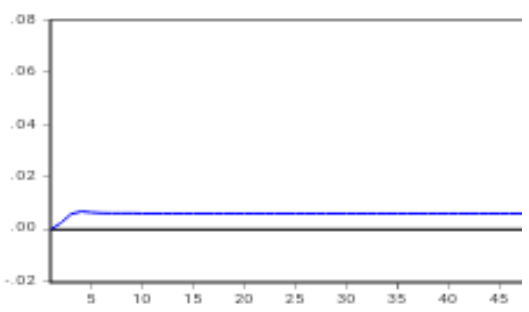

Response of LNPEMB PROPERTI to FDR

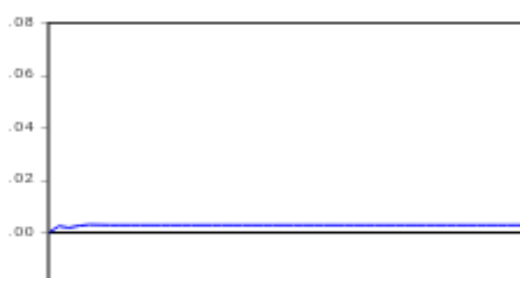

Figure 4. Test Results Graph Impulse Response Function (IRF)

As for the response property financing due to their variable shock $B I$ rate in the coming period as a whole is negative. It can be seen from the observation line is below the line standard deviation of 0.0 . In the period from the beginning to the period of the 6th had been fluctuating up in the end, the response was stable until the end of the observation period with a standard deviation of -0.007878 .

IRF analysis then goes on to explain property finance response to shocks that occurred on inflation. In the first period to 7 fluctuations response from property financing. But then stabilized in the next period until the end of the observation period with a standard deviation of 0.006109 . Overall the property finance response to inflation is positive, visible from the observation line is above the standard deviation of 0.0 .

Analysis IRF third is the variable shock IPI for property financing was positive. The results make it clear that in the early period until the 4th period there was an increase in positive pretty good and fluctuate until the period 7th. But in the next period until the end began to stabilize in the standard deviation of 0.015081 .

Last IRF analysis is a response peroperti financing for their shocks of internal variables that FDR bank. Shock is given a positive response 
to the financing of the property. There is an increase until the 6th period. And stable until the end of the observation period on the standard deviation of 0.002893 .

To easily view response then presented a summary of the Property Financing IRF test results as follows table 8.

Table 8. Summary of Test Results IRF

\begin{tabular}{ll}
\hline \multicolumn{1}{c}{ Shock Variables } & \multicolumn{1}{c}{ Response Property Financing } \\
\hline Pemb. Property & Positive, stable from period ke- 7 \\
FTV & Negative, stable from period to 5th \\
BI rate & Negative, stable from period to 7th \\
Inflation & Positive, stable from period to 8th \\
IPI & Positive, stable from period to 8th \\
FDR & Positive, stable from period to 7th \\
\hline
\end{tabular}

\section{Forecast Error Variance Decomposition (FEDV)}

In the last analysis is a method VECM Forecast Error Variance Decomposition (FEDV) are useful to support the results of previous analysis. FEDV provide information the contribution of a variable to change the variable itself and other variables in the coming period. Values are in the form of a percentage of the analysis results so they will know the variables that contribute most to the specific variables. Here is the result of the analysis FEDV:

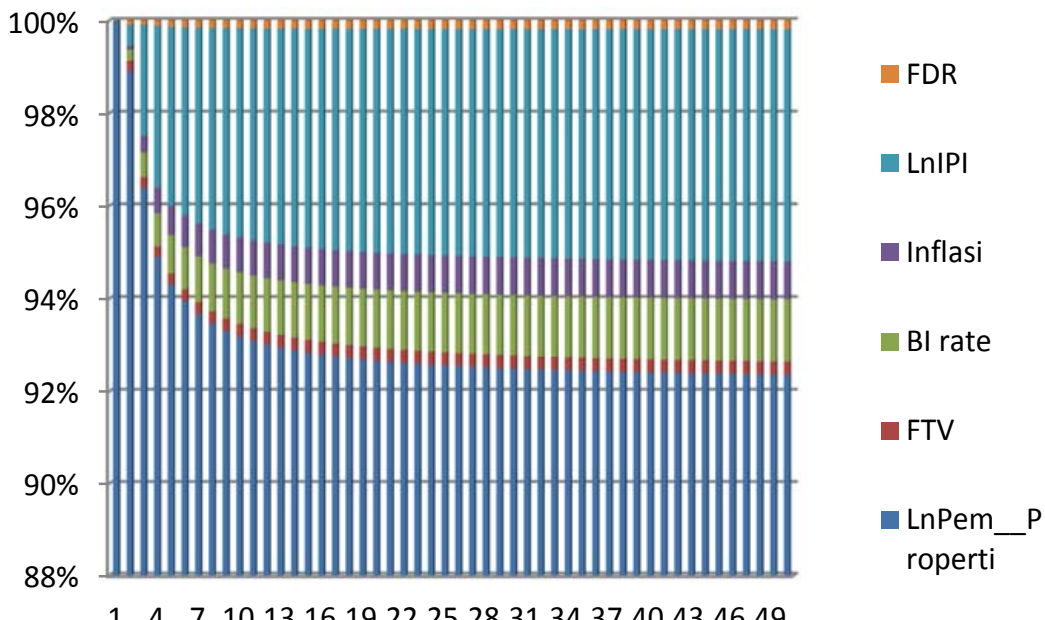

Figure 5. FEDV Graph

Based on the figure 5 and test results FEDV in annex 3.9 shows that the largest contribution to the diversity of the variables affecting the Property Financing is herself with an average of $93.09 \%$. In the 
early period, influential Property Financing $100 \%$ but then declined in each period be $92.36 \%$ at the end of the period.The second largest IHTIFAZ - JIEFB contribution comes from the IPI variable with an average contribution of $4.55 \%$. Variable sennatiasa IPI has increased in each period with contributions at the end of the period amounted 5:00\%. Then, a third contribution of variables affecting diversity Property Financing is the $\mathrm{BI}$ rate by the average value of $1: 17 \%$. In the early period accounted for $0 \%$ and then increased to $1: 34 \%$ at the end of the period.

The next largest contribution to the inflation variable average contribution is $0.75 \%$. Each period has increased contributions until the end of the period amounted to $0.82 \%$. Next is the contribution of variable FTV ranks fifth with an average value of $0: 27 \%$. This variable has also increased in each period until the end of the period contributed $0.28 \%$. The smallest contribution came from FDR variable with an average of $12: 16 \%$. FDR variable contribution to variable Property Financing increased. At the beginning of the period only accounted for $0 \%$ and then at the end of the period contributed to $0: 18 \%$. The complete results of the test FEDV contained in the annex 3.9.

\section{DISCUSSION}

\section{Property Financing}

IRF test results showed that the response to the shock of the property financing easing policy variables FTV is negative. The average contribution FTV variable to variable property financing based on test results VD is very small in the amount of $0.27 \%$. There are several reasons to be negative FTV policy namely that the purchase of the house by the client is a long-term decision and depends on his perceptions of economic conditions. If the economy is not yet clear, the customer usually refrain from buying the house so as to make the distance (time lag) on the effectiveness of the policy.

In 2015 , economic growth is slowing in the amount of $4.7 \%$ in the 1st half, down fromthe same period in 2014 amounted to $5.17 \%$. This was triggered by the global economic slowdown including Indonesia trading partner countries as well as the weakening of commodity prices in the international market. In addition, due to uncertainty in financial markets associated with the uncertainty of the benchmark interest rate The Federal Reserve (Ariyanti, 2015).

Property loan growth also slowed in 2015 which grew only $13.6 \%$ lower than a few months earlier by $14.1 \%$ in June, (Sandy, 2015) so that many developers are already postpone the project due to the weakening of the Indonesian economy at the time. Many developers are delaying the project led to the banks a bit difficult to work with developers so that their FTV policy can not be directly perceived. 
FTV ineffectiveness easing policy in 2015 have been addressed by the government and Bank Indonesia issued Regulation No. 18/16/ $\mathrm{PBI} / 2016$. This regulation is published in order to improve an earlier policy to reach the phase ability to resist cutting property financing and yet strong enough to boost growth financing. This policy further loosen LTV ratio/FTV than the previous policy. These results are also consistent with research Marisza (2015) concluded that the policy tightening LTV failed to suppress the amount of credit property in Lampung Province which caused demand for mortgages remains high.

\section{BI Rate}

The results of the analysis of IRF explains that the BI rate to variable Shock response of property financing is negative. Then from the VD analysis, shows that the variable BI rate accounted for $1: 17 \%$ on average observation period. The negative effect of the BI rate property finance in line with the existing theory. BI rate which is the reference rate set by Bank Indonesia will affect Lending Rate (prime lending rate) in the banking system. Then the prime lending rate will be the reference banks in increasing or decreasing the quantity of credit allowing the occurrence of bad debts. However, in Islamic banking, BI rate does not directly affect the financing for Islamic banking does not apply the system of interest rates. BI policy rate is raised or lowered not necessarily make Islamic banks raise pricing of financing, including financing of the property. Because it is associated with the pricing of the predetermined contract and can not be changed in mid-financing agreement. Only when the BI rate is low, the level of margin able competitive Islamic banking. Meanwhile, when the BI rate is high, Islamic banks have no risk of competing for the results of third-party funds, for DPK in conventional banks offering higher interest rates (Sudarwanto, 2011). Thus, the BI rate negatively affect property financing. This result is also the same with research Marisza (2015) back, that interest rates and inflation negatively affect the amount of the mortgage portfolio in Lampung province.

\section{Inflation}

The results of the analysis of IRF explained that the shocks of inflation variable positive effect on response property financing. In connection with its contribution to the variable property financing, inflation accounted for $0.74 \%$ in the period average. The big difference in the hypothesis with the results of the property can be argued that in the inflation rate has no effect on the decline in property finance for property no relation to the price of land is never down. Every year the land continues to increase, especially in places that are strategic and potential economic growth. The price of land followed by property prices always go up every year. According Maisarah (2015), there are several 
reasons property prices do not decline, one of which is the interest of Indonesian society and foreign investment in the property is quite IHTIFAZ - JIEFB high. Thus, prices rise (inflation) has positive effect and keep improving the property finance portfolio. The results of this study do not differ from research Qoyum (2015) which concluded that the BI rate and inflation does have a negative effect on credit growth in the banking and finance growth in Islamic banking.

\section{IPI}

Results of processing by the analysis of IRF is the positive impact generated for their shock variable IPI for property financing. The average contribution to the financing of his property by $4: 54 \%$. The underlying reasons for the positive influence of the IPI as a proxy for economic growth to finance the property is that it is theoretically possible credit at banks including Islamic banking has a causal relationship with economic growth. This relationship occurs because of the higher loans disbursed banks, will spur economic growth in the sector given the credit. In this case, the credit be used as a driver of economic growth. Conversely, when high economic growth will lead to increased credit demand.And if economic growth is less excited or unstable, the demand for credit will also be sluggish (Purba, 2011). Because the property finance is one of demand for credit, of course this theory is relevant to the financing of the property that is affected positively by IPI. The above theory is corroborated by studies of Syahfitri (2013) with the result that economic growth positive effect on bank credit.

\section{FDR}

Based on the analysis of IRF explained that the response of financing peroperti for their shocks of the bank's internal variables that FDR was positive. VD analysis that FDR variables are contributing to an average of $0: 16 \%$. In determining the amount of credit, banks typically will see first if the funds already collected have been channeled to the maximum or even have not been channeled. When the number of high proficiency level of third party funds, then the bank will be extending credit. In Islamic banking, FDR ratio being the size of it. This means that the higher the ratio of FDR that exist in Islamic banking, Islamic banking, the ability to discharge high and increasing financing are also included in the property finance portfolio. This argument is the same as the results of research conducted by Dwianingrum (2015) which provides information that the number of credit mortgages from banks is observed more into account the changes that occur in the variable DPK and LDR while other variables such as NPL, CAR, ROA, ROA and BI rate underestimated. 


\section{CONCLUSION}

Referring to the results of research by the method of Vector Error Correction Model (VECM) and the discussions that have been described in discussion of the obtained several conclusions as follows. Firstly, FTV relaxing its negative impact on the increase in property finance and $\mathrm{BI}$ rate as macroeconomic variables have a negative influence. Secondly, Inflation, IPI and FDR a positive impact on property finance. Thirdly, FTV rexing policy in 2015 has not been effective in improving the property financing. This policy is only able to make property financing does not decline it. Meanwhile, other variables, namely macroeconomic and internal bank also affect the financing of the property so that the property finance portfolio, Islamic banking can not be ruled out. Policymakers are expected to consider a lot of things, especially the economic conditions at the time of going to release a policy, so the prediction effectiveness of the implementation of a policy can be implemented properly. The variables studied also should be added, especially Islamic banking internal variables, so the results obtained can be more thorough.

\section{REFERENCES}

Adzimatur, Fauziyyah. (2016). Faktor-faktor yang mempengaruhiBesaran Pembiayaan Perbangkan Syariah di Indonesia. Jurnal Al-Muzara'aah, ISSN p:2337-63333; e: 2355-4363.

Ascarya. 2012. Alur Transmisi dan Efektifitas Kebijakan Moneter Ganda Di Indonesia. Buletin Ekonomi Moneter dan Perbankan. Vol. 14, No. 3. hlm. 283-315.

Aviliani. (2015). The Impact of Macroeconomic Condition on The Bank's Performance in Indonesia. Buletin Ekonomi Moneter dan Perbankan. Vol. 17 No. 4 April 2015.

Aziz, Mohammad Khaerul.2016.Kausalitas Upah Minimum Regional dengan Laju Inflasi di Provinsi D.I. Yogyakarta Tahun 1990-2012 (dalam Perspektif Ekonomi Syari'ah). Skripsi. Fakultas Ekonomi dan Bisnis Islam, Universitas Islam Negeri Sunan Kalijaga Yogyakarta.

Bank Indonesia. (2014). Makroprudensial Mencegah Gelombang Krisis. GERAI Info Bank Indonesia Edisi 51 Tahun 5 Newsletter Bank Indonesia.

Bank Indonesia. (2015). Frequently Asked Questions Peraturan Bank Indonesia No.17/10/PBI/2015 tentang Rasio Loan to Value atau Rasio Financing to Value untuk Kredit atau Pembiayaan Properti dan Uang Muka untuk Kredit atau Pembiayaan Kendaraan Bermotor.

Bank Indonesia. (2015). Kebijakan Makroprudensial di Bank Indonesia. Training of Trainers Kebanksentralan Khusus Dosen Pengampu. Departemen Kebijakan Makroprudensial Bank Indonesia Februari 2015.

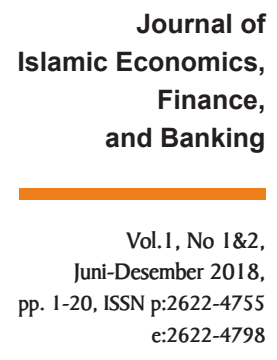

Finance,

Desember 2018, e:2622-4798 
Benny, Niara Ayu. (2013). Perbedaan Tingkat Kebugaran Jasmani Siswa yang Mengikuti Ekstrakurikuler Bola Basket dengan Futsal di SMPN 1 Paseh Kabupaten Bandung Tahun 2013. Skripsi. Universitas Pendidikan Indonesia.

Budiyanti, Eka. (2015). Kebijakan Pelonggaran Ketentuan Loan to Value (LTV) Sektor Properti. Info Singkat Ekonomi dan Kebijakan Publik. Vol. VII, No. 10/II/P3DI/Mei 2015 Sekretariat Jenderal DPR RI.

Dwianingrum, Titia. (2015). Determinasi Tingkat Penyaluran Kredit Pemilikan Rumah (Periode Setelah Kebijakan Loan to Value). Jurnal Ilmiah. Fakultas Ekonomi dan Bisnis Universitas Brawijaya Malang.

Giannini, Nur Gilang. (2012). Faktor yang Mempengaruhi Pembiayaan Mudharabah pada Bank Umum Syariah di Indonesia. Accounting Analysis Journal Universitas Negeri Semarang. ISSN 2252-6765.

Gumiwang, Adi Gemilang. (2009). Respon Tingkat Pengembalian Saham Sektor Perbankan terhadap Fluktuasi Variabel-Variabel Makroekonomi di Indonesia Periode Januari 2000-Desember 2008. Skripsi. Program Studi Manajemen Konsentrasi Keuangan Fakultas Ekonomi Universitas Ekonomi.

Heratri, Komala. (2015). Analisis Volatilitas, Kebijakan Loan to Value dan Variabel Makroekonomi terhadap Return Saham Sub Sektor Properti dan Real Estate di BEI. Tesis. Sekolah Pascasarjana Institut Pertanian Bogor. International Shari'ah Research Academy for Islamic Finance (ISRA). 2012. Islamic Financial System: Principles \& Operations. Malaysia: ISRA.

Karim, Adiwarman A. (2013). Bank Islam. Analisis Fiqih dan Keuangan. Jakarta: PT Raja Grafindo Persada.

Maisarah, Siti. (2015). Determinan Makroekonomi dan Spesifik Bank Terhadap Kredit Macet Perumahan Di Indonesia. Jurnal IImiah Fakultas Ekonomi dan Bisnis Universitas Brawijaya.

Marisza, Princes Dianria. (2015). Analisis Pengaruh Kebijakan Loan to Value (LTV), Inflasi, Suku Bunga Kredit, dan Loan to Deposit Ratio (LDR) terhadap Penyaluran Kredit Pemilikan Rumah Provinsi Lampung Periode 2010:01-2014:09. Skripsi. Universitas Lampung.

Mishkin, FS. (2001). The Economics of Money, Banking, and Financial Markets. New York: Columbia University.

Nasir, M. Abd. (2014). Analisis Komponen Kebijakan Makroprudensial Bank Indonesia untuk Mengendalikan Volatilitas Nilai Tukar, Likuiditas, dan Total Kredit Perbankan, 2004.1-2012.12. Tesis. Program Studi Ilmu Ekonomi dan Studi Pembangunan Universitas Gadjah Mada Yogyakarta.

Natidya, Benita Lenora. (2014). Reaksi Pasar terhadap Kebijakan Bank Indonesia tentang Pembatasan Loan To Value pada Kredit Pemilikan 
Rumah: Analisis Saham Sektor Perbankan dan Properti. Skripsi. Fakultas Ekonomika dan Bisnis Universitas Gadjah Mada.

Natsir, Muhammad. (2008). Analisis Empiris Efektivitas Mekanisme Transmisi Kebijakan Moneter di Indonesia Melalui Jalur Ekspektasi Inflasi Periode 1990:2-2007:1. Jurnal.

Peraturan Bank Indonesia No. 17/10/PBI/2015 tentang Rasio Loan to Value atau Rasio Financing to Value untuk Kredit atau Pembiayaan Properti dan Uang Muka untuk Kredit atau Pembiayaan Kendaraan Bermotor.

Peraturan Bank Indonesia No. 18/16/PBI/2016 tentang Rasio Loan To Value untuk Kredit Poperti, Rasio Financing to Value untuk Pembiayaan Properti dan Uang Muka untuk Kredit atau Pembiayaan Kendaraan Bermotor.

Pradana, Y dan R.D Sampurno. (2013). Analisis Pengaruh LDR, CAR, ROA, dan Faktor Eksternal Perbankan terhadap Volume KPR pada Bank Persero Periode 2008-2012. Journal of Management. Vol. 2 No. 3 HIm. 1, ISSN: 2337-3792.

Purba, Alexander F. (2011). Analisis Kausalitas dan Kointegrasi Kredit Perbankan dan Pertumbuhan Ekonomi di Sumatera Utara. Skripsi. Fakultas Ekonomi Universitas Sumatera Utara Medan.

Purnawan, Muhammad Edhie dan M. Abd.Nasir. (2015). The Role of Macroprudential Policy to Manage Exchange Rate Volatility, Excess Banking Liquidity and Credits. Buletin Ekonomi dan Perbankan. Volume 18. Nomor 1.

Qoyum, Abdul. (2015). In Search for Islamic Macroprudential Policy: Concept and Practice in Indonesia. Jurnal dipresentasikan dalam Islamic Conference di Bahrain.

Rejeki, Desi Budi. (2015). Pengaruh Dana Pihak Ketiga (DPK), Non Performing Loan (NPL), Dan Bi Rate, Terhadap Tingkat Penyaluran Kredit Perbankan (Studi Pada Bank Umum Swasta Nasional Devisa Di Indonesia Periode Tahun 2007-2011. Tesis. Program Studi Manajemen Universitas Gadjah Mada Yogyakarta.

Sahabat, Imaduddin. (2009). Pengaruh Inovasi Sistem Pembayaran terhadap Permintaan Uang di Indonesia. Tesis. Fakultas Ekonomi Program Pascasarjana Universitas Indonesia.

Saekhu. (2015). Pengaruh Inflasi terhadap Kinerja Pembiayaan Bank Syariah, Volume Pasar Uang Antar Bank Syariah, dan Posisi Outstanding Sertifikat Wadiah Bank Indonesia. Jurnal Economica Vol. VI Edisi 1.

Saraswati, Ida Ayu Putri. (2014). Analisis Kebijakan Bank Indonesia tentang Loan to Value pada PT. Bank Tabungan Negara (Persero). Tbk Cabang Singaraja. Jurnal Vol. 4 No. 1 tahun 2014 Fakultas Ekonomi dan Bisnis Universitas Pendidikan Ganesha Singaraja. 
Setifandy, Tegar. (2014). Analisis Pengaruh Kinerja Keuangan dan Makroekonomi terhadap NPL KPR (Studi Kasus pada Bank Umum IHTIFAZ - JIEFB Periode 2010-2013). Jurnal Ilmiah. Fakultas Ekonomi dan Bisnis Universitas Brawijaya Malang.

Syahfitri, Ika. (2013). Analisis Kredit Perbankan dan Pertumbuhan Ekonomi Indonesia. Skripsi. Fakultas Ekonomi dan Manajemen Institut Pertanian Bogor.

Surat Edaran Bank Indonesia No. 15/40/DKMP tentang Penerapan Manajemen Risiko pada Bank yang Melakukan pemberian Kredit atau Pembiayaan Pemilikan Properti, Kredit atau Pembia yaan Pemilikan Properti dan Kredit atau Pembiayaan Kendaraan Bermotor.

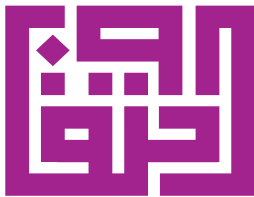

\section{IHTIFAZ}

UNIVERSITAS AHMAD DAHLAN

Kampus 4

Universitas Ahmad Dahlan Jl. Ringroad Selatan, Tamanan

Banguntapan, Bantul Yogyakarta 5519 